\title{
STICHIC AND STANZAIC POETIC FORM IN ESTONIAN TRADITION AND IN EUROPE
}

\section{MARI SARV}

In the current article I am trying to find out why two layers of Estonian song-tradition - one forming part of common Baltic-Finnic heritage and the other belonging together with European rhymed folk-song and ballad tradition - are so remarkably different in several aspects. I have, therefore, placed them into broader, European context, exploring the decline of non-stanzaic or stichic verse-forms and the expansion of rhymed, stanzaic verse-forms. Both organization principles of texts are or have been known all over Europe, but the earlier stichic forms have for the most part given way to rhymed stanzaic verse-forms, which have-sooner or later-become predominant almost everywhere in Europe. As the differentiation is explicit in the case of Estonian and the parallel traditions have been recorded simultaneously in quite recent times, the analyzing and contextualising of Estonian tradition-layers might shed some light to the developments in European traditional poetics as well.

Keywords: Estonian folksong, poetic form, stichic vs. stanzaic verse-forms, rhyme, orality and literacy studies, development of individualism, ballads.
$V$ članku želim ugotoviti, zakaj sta dve plasti estonskega pesemskega izročila - ena pripada skupnemu baltskofinskemu izrocilu, druga pa evropski ritmizirani pesemski tradiciji in baladam - v mnogočem tako različni. Zato sem jih postavila $v$ širši evropski kontekst in raziskala zamiranje nekitičnih oblik pesmi in naraščanje kitičnih verznih oblik. Obe obliki besedila pesmi sta bili poznani po vsej Evropi, toda nekitična oblika je bila kmalu nadomeščna s kitično in je tako postala najpogostejša verzna oblika povsod po Evropi. Ker je diferenciacija obeh tradicij v estonskem izrociilu zelo značilna, obe sta bili $v$ zadnjem času zapisani istočasno, lahko analiza in kontekstualizacija estonskih plasti izročila osvetlita tudi razvoj v evropski pesemski tradiciji.

Ključne besede: estonske ljudske pesmi, pesemska struktura, verzna in kitična forma, rima, ustno in pisno, razvoj individualizma, balade.

Wie ich unterwegens in der Erndte-Zeit die Schnitter im Felde antraf, hörete ich allenthalben ein wüstes Gesänge, welches diese Leute bey ihrer Arbeit trieben, und vernahm von einem Prediger, daß es noch alte Heidnische Lieder obne Reimen wären, die man ibnen nicht abgewöhnen könte, wiewol man doch noch gerade auch die Esthische Sprache in eine Reim-Kunst zu bringen sich bemühete, und schon viele Evangelische Gesänge in Esthische Verse gesetzet hätten. (F. C. Weber, Das Veränderte Rußland. Frankfurth 1721: 70, cit. Laugaste 1963: 81)

\section{TEXTUAL AND MUSICAL STRUCTURE OF ESTONIAN FOLK-SONGS}

In Estonian song-heritage there are two clearly differing layers: 1) genuine, more archaic tradition (in Estonian regilaul) which forms part of a broader tradition common to several Finno-Ugric peoples around the Gulf of Finland in the Baltic Sea; 2) newer, rhymed song tradition, which in Estonia is clearly foreign, mostly German import and spread only since $17^{\text {th }}-18^{\text {th }}$ century. As for the structure of text, those two layers of Estonian song-tradition 
represent different text making principles: (1) stichic or linear (where one can add lines voluntarily one by one) in the case of regilaul, and (2) stanzaic (where lines are bound together in regular larger units-stanzas) in the case of newer songs. Regilaul-tradition is characterized by alliteration, parallelism and varied repetition, more extensive variation and more extensive use of formulae. In stanzaic songs lines are often bound together by rhyme or assonance and their text is much more stable. The musical structure is in accordance to the structure of text: in the most cases of regilaul the recurrent tune encompasses one line, often with addition of a slightly varied version of it for to repeat the text line by the co-singers; in the case of rhymed stanzaic songs the recurrent tune encompasses in most cases at least two lines, more often four lines, sometimes with additional chorus part.

Text example of Estonian regilaul (Tampere et al. 2003: 167-168, translation by H. Mürk)

Viere, viere, pääväkene, viere nü̈̈d looja vettä müedä, lasõ kasõlatvu kaudu!

Ei oló aega pääväl veerdä: pä̈uv soeb sulastó päidä, kammib karjalastó päidä, arib päidä armõtumil, laamib neiu lakkasida.

Suga kukkuskäest merese, arja külmä al'likassõ, laamilauda laenõtôssô, kammi suurõ kalda'esse.

Päe läks Pietri palvõelle: "Pieter, sa pühä mehe poega, Andrus, sa amótmehe poega, mine tuó mu suga merestä, arja külmä al'likasta, laamilauda laenõtôsta, kammi suurô kalda'estä!”

Pieter ei võtnud palvốeidä, Andrus äidä sõnumida.

Päe läks ise illukesi, müedä tiedä til'lukene, müedä vettä vähikene, müedä kallast kaunikene, müedä muad madalukene, tôi oma sua merestä, arja külmä al'likasta, laamilaua laenótôsta
Roll along, roll dear sun,

Roll now by the creator's waters, Sink down by way of the birch tree crowns!

The sun has no time to roll along: the sun is combing the heads of the serfs, combing the heads of the herder children, brushing the heads of the wretched, smoothing the tresses of the maidens.

The comb fell from the [sun's] hand into the sea, the brush into the cold spring, the rake into the waves, the comb onto a vast coast. The sun went to beg St. Peter: "Peter, you son of a holy man, Andrew, you son of an artisan, go get my comb out of the sea, the brush from the cold spring, the rake from the waves, the comb from the vast coast!"

St. Peter did not listen to this prayer, St. Andrew did not heed these good words. The sun went little by little, the tiny one along the path, the small one along the water, the pretty one along the coast, the setting one along the land. The sun brought the comb from the sea, the brush from the cold spring, the rake from the waves.

Text example of Estonian stanzaic song (from the manuscripts of Estonian Folklore Archi- 
ves - RKM, Mgn. II 1023), true rhymes in bold, morphological rhymes (homeoteleuton) underlined.

Peigmees, miks mind maha jätsid, omal uue pruudi võtsid, ai äbi, äbi, äbi, omal une pruudi võtsid.

Mina niikui roosilill, kullerkuppja jaanikann.

Minu aiast marjad nopsid, puude otsast ôn ad vôtsid.

Neid siis une prundil viisid armuga neid kätte andsid.

Siis mina tundsin valu sies, et minu peiu petis mees.

Ö̈sel petab pimedas, päeval vannub valge ies.

Vannub ihu, vannub inge, vannub oma lubamist.

Sest meesterahvast uskuda on niikui soola külvata.

Meesterabval libe kiel, lübikesed juuksed, kerge meel.

Mu, armas õde, tule sa ma lähen ära nutuga. Ai valu, valu, valu, lähen ära nutuga.
My bridegroom, why did you leave me, why did you took a new bride? Oh, shame, shame, shame, you took a new bride.

I am like a rose flower,

like a globe-flower and primrose.

You picked the berries from my garden, you took the apples from the trees.

And then you carried those to your new bride, and gave to her with love.

Then I felt pain inside, because my bridegroom is a cheater.

At night, when it is dark, he is cheating, in daytime, when it is light, he makes vows.

He vows his body and his soul, and he vows all his promises.

To believe what the men say is like to sow salt.

Men do have oily tongue, short hair and light mind.

My dear sister, come along, I am leaving in tears.

Oh, pain, pain, pain, I am leaving in tears.

There is notable difference in the melodic structure of the two song-styles as well. Urve Lippus in her musicological study "Linear Musical Thinking" (1995) makes differentiation between linear and harmonic musical thinking. In harmonic music all the notes of the melody have some relation to underlying harmony, whether or not that harmony is realized in sound. In linear music the harmonic component - the organization of pitches into chords and chord relations - is missing, a note or melodic figure is simply a constituent of melody (Lippus 1995: 10-11). In addition to regilaul and some other traditional music, Lippus admits also medieval European music to have the characteristics of linear music (ibid: 7). In the melodies of regilaul harmonic basis can be discerned only sporadically, while rhymed songs in Estonian tradition have clearly harmonic structure. 


\begin{tabular}{|l|l|}
\hline Linear music & Harmonic music \\
\hline $\begin{array}{l}\text { The hierarchical structures of music are } \\
\text { limited to a small number of levels. }\end{array}$ & $\begin{array}{l}\text { Musical structures can have many hierarchical } \\
\text { levels. }\end{array}$ \\
\hline $\begin{array}{l}\text { There is considerable flexibility of pitch and } \\
\text { temporal organization; it is spontaneous. }\end{array}$ & $\begin{array}{l}\text { The organization of pitch and time can achieve a } \\
\text { high degree of precision. }\end{array}$ \\
\hline $\begin{array}{l}\text { The most important features of speech } \\
\text { prosody can survive in the musical } \\
\text { performance. }\end{array}$ & $\begin{array}{l}\text { The qualities of speech are depending on, and } \\
\text { sometimes distorted by properties of the melody. }\end{array}$ \\
\hline
\end{tabular}

The distinctive features of linear and harmonic music (according to Lippus 1995: 150).

The features characteristic to linear and harmonic music are comparably reflected also in the principles of text organization of Estonian folksong-layers. In stichic composition the hierarchical structures between the lines (parallelism and varied repetitions) occur regularly but voluntarily, in stanzaic style they are regulated, forming the essence of the text-structure, often in the interaction of rhymes and stanza forms. The variation is considerably more prevalent in the case of stichic than stanzaic song-style. The stichic mode seems to represent more archaic way of composition and stanzaic mode more modern way comparably to the linear and harmonic modes in the case of music.

Lippus states that linear music exists mainly as an oral phenomenon, whereas the complexity of harmonic music requires more often notation, which is a practice peculiar foremost to Western music (Lippus 1995: 14-15). That applies to the Estonian traditionlayers likewise. Regilaul has belonged first and foremost to oral tradition, i.e. those songs have existed mostly in live performance and have been learnt through listening and practicing, without the help of written scores, while newer songs have brought along a considerable tradition of handwritten songbooks for practical purposes. One of the most remarkable authors in orality and literacy studies, Walter Ong, in his book Orality and Literacy, has emphasized memory's centrality in oral culture and offered a list of characteristics that would more broadly characterize the modes of thinking and verbal expression of oral cultures (Ong 1982: 36-49). Despite their employment of various mnemonic devices, these characteristics do not unequivocally refer to a word-for-word manner of passing on of the texts, practice of continuous adjustment of the texts' contents to make them relevant to the times are equally important. Characteristics noticed by Ong match markedly well with regilaul tradition (Sarv 2008: 122-124). In particular the first one of those characteristics - oral expression is rather additive than subordinate - fits well within the differentiations discussed so far. Hierarchic or subordinate structure of stanzaic songs manifests itself at the first instance in the division of text into regular units in addition to the division of text into lines. The inner organization of stanzas by means of rhymes and rhyme-schemas may add an additional dimension to the hierarchicity. Another relevant characteristic is the redundancy or copiousness of the expression in oral culture in order to ensure that the information passed on would not get lost during the communication process. In oral society one of the functions 
of poetic form is to preserve important information, therefore it is reasonable to use lot of repetitions, varied repetitions, parallelistic statements and formulae. Those means are very essential to regilaul tradition where text advances quite slowly compared to rhymed songs. Stanzas in newer song tradition are not so apt to linger at one subject or idea. The rhyme construction in itself seems to support advancing of content - it would be problematic in such a form to repeat the ideas variedly as there are barely any synonymous rhyme pairs. But even when the rhyme structures are not very rigid or when the rhymes have been lost completely in the popular translation from a foreign language, lack of systematic parallelism alone affords faster and more fluent development of the content. In the example of Estonian stanzaic song above, rhyming is not a rule but an option; the couplets with morphological rhymes only or without rhymes at all exhibit some traits of traditional parallelism; BalticFinnic traditional parallelism and rhyme seem quite systematically to exclude each other (cf. Preminger and Brogan, eds. 1993: 1055). Though, in spite of the lack of the regular rhyme, in the newer layer of songs, the musical structure and the eventual regular chorus prescribe stanzaic structure very clearly.

Thus, on the basis of the textual and musical structure of songs as well as on the basis of the historical spread of the tradition-layers, regilaul tradition belongs rather to oral culture, whereas rhymed stanzaic songs have got more features referring to literate way of expression. As a working hypothesis we may assume that this might be true in the case of stichic and stanzaic poetic tradition more generally i.e. stanzaic rhymed poetic form has been spread in the conditions of literacy, alongside with the way of thinking specific to it. Paradoxically, even pre-literate forms of folklore, at least in Europe, could have been noted down only after the spread of literacy, i.e. already in conditions of literacy. Besides, oral transmittance of folklore has not been ceased in literary cultures either and the traditions have maintained features necessary for memorization and performance. The functions of folklore, though, have been changed partly due to the spread of literacy, and this process may manifest itself in the content as well as in the form of folklore texts.

\section{STICHIC AND STANZAIC VERSE FORMS IN EUROPEAN TRADITION}

In European tradition the stichic verse associates mostly with epic songs or old epics like Homer's epics, Germanic alliterative epics, Finnish epic Kalevala, Serbian epic songs, Romanian epic songs, Russian bylinas etc. Lyric non-stanzaic songs are, however, in different extents, known at least among Baltic-Finnic, Slavic and Baltic peoples. The stanzaic rhymed song-tradition is represented by European ballad tradition, as well as by Christian hymn tradition and by various species of folk-songs. In European tradition stanzaic structures are mostly created with the aid of rhymes marking the end of the lines. Undoubtedly rhymes and stanzas as poetic structures support each other and are in mutual interaction, but they do not inevitably have to co-exist. Latvian folksongs, for example, consist regularly of four 
trochaic lines without rhymes, whereas in Romanian epic tradition rhymes do occur commonly, however without inducing the regular stanzas (Hiebert Beissinger 1988).

T. Brogan in The New Princeton Encyclopedia of Poetry and Poetics states that most of the worlds 4000 languages lack the rhyme in their poetries altogether and that the rhyme is not originally native to any European language (Preminger and Brogan, eds. 1993: 1061). Compulsory rhyme with metrical functions has begun to spread in Europe in medieval times or slightly before. According to Gasparov, when Greek and Latin poetry lost their quantitative basis, the new predominantly syllabic verse-form needed a device to make lines more coherent and rhyme, which regularly marked the end of line, did fit to fulfil this function (Gasparov 1996: 96). I am not going to discuss here the origins of European rhyme, whether it was spontaneous, derived from the rhyming tradition of prose, or followed the models of Irish or Arabian poetic traditions. Apparently regular metrical rhyme emerged almost simultaneously in Latin hymn tradition and in the Occitan and Provençal vernacular songs (Preminger and Brogan, eds. 1993: 1058; Abondolo 2001: 241). The Latin hymns did spread along with Christendom, which in turn played a significant role in the spread of literacy. Along with hymnody as well as balladesque folksongs the rhyme began to spread all over the Europe in Christian poetry in Latin, in vernacular poetry, as well as in folk poetry. In Scandinavia, the alliterative poetics was replaced by rhymed poetic tradition in $14^{\text {th }}$ century, in England and Germany even before. Alongside with rhymed songs, the peoples in Eastern Europe have to some extent preserved the older stichic tradition until nowadays. Thus, the spread of rhymed stanzaic traditions coincides in certain extent to the spread of literacy and intersects with it in Christian hymn tradition, but that fact alone does not explain the overwhelming spread of popular rhymed traditions.

Moreover, it has been noted, that compulsory rhyme occurs mostly in those poetic forms, which use accentual verse systems and rarely in quantitative verse systems. The choice of verse system in turn has to accord with the prosodic system of the language stress-timed languages with typical features like strong dynamic stress and reduction of unstressed syllables naturally favour accentual verse systems (Lotman 1998: 1859, 2068). The diminishing of inflectional endings can be seen as the one cause or presupposition of the development of "real" rhyme, as opposed to the morphological one (Preminger and Brogan (eds.) 1993: 1063). This is without a doubt the case in Germanic languages but this applies for the changes in Estonian tradition as well - during the $13^{\text {th }}$ to $16^{\text {th }}$ centuries significant changes in the Estonian language system took place; it lost several inflectional endings and developed some flectivity (see e.g. Viitso 2003). Those transformations, in turn, might have occurred due to the contacts with Germanic languages (e.g. Wiik 1996: 238), however, there are several opinions on this question. The language changes disturbed the basis and coherence of regilaul versification and this, together with emerged flectivity shaped a favourable linguistic ground for the acceptance of rhymed poetry. Estonian newer songs have given up the use of archaic word-forms, so common to the regilaul tradition; more often they use literary language with some eventual dialectal features only. 


\section{CONTENT, FUNCTIONS AND SOCIO-CULTURAL BACKGROUND OF SONGS}

So far we have discussed here the diversities between Estonian older and newer song-tradition in textual and musical structure and in the language-use. The difference between the tradition-layers is, however, probably most salient in the content and function of songs. Among the main subjects of stanzaic rhymed songs are love and tragic, often death, as well as life of nobility, chivalry, (lost) homeland, patriotism and realistic journeys during army service or seafaring (cf. Tedre 2008: 432), which barely occur in regilaul tradition. Common thematic fields for both traditions are social protest, everyday milieu and mockery. In regilaul tradition the central subjects deal with family and kinship matters, peaks of life cycle and calendar/work cycle, and mythological issues. The divergence of thematic fields refers clearly to the different phases of the social thinking - the subjects of older songs refer to the collectivism and kinship society, the newer songs dealing with personal feelings and deeds as well as with historical events, belong clearly to an individualistic society. Both traditions have extrapolated the most substantial clichés and values characteristic to its societal way of thinking for to build up the songs, in accordance of the function of either song tradition.

The multi-functionality of poetic expression in traditional societies is probably not exceptional, but in brief, the purpose of regilaul seems to be to support the world order, the cosmos; singing of songs in significant, liminal, dangerous or hard times has been likely meant to secure the eternal recurrence and continuity, the singing itself forming a part of folk-customs, being itself a ritual and/or magical act. In the scholarly studies, now and then, several mythological songs have been construed relating to time cycles, as the song cited above, where falling and rising of the comb has been interpreted to represent the amplitude of the movement of sun (and its rays) during the yearly cycle, with saints referring to calendar dates (Hiiemäe 2006), or as in case of the mythological brother and sister interpreted as the guards for the alternation of seasons (Lintrop 2001: 44). The newer, rhymed songs, often complemented by instrumental music and dancing, have served as entertainment, mostly free from evident ritual relations. Ülo Tedre, in his overview of Estonian folklore, summarizes the functionality of song-layers in short: "regilaul was first and foremost an accompaniment for works and activities, newer song fulfilled the times of rest" (Tedre 2008: 433).

There is a recognizable difference in the time conception of song-layers too. The one main feature characteristic to ballad tradition is its narrative mode, presenting of a story which moves on in time, and this holds true for the core of the stanzaic songs in Estonian tradition as well. The corpus of the older Estonian songs is mostly lyrical, the songs usually do not tell stories, at least not the realistic individual stories, but rather tell about the stable or constantly recurrent issues. If there are narratives - and there are more of them in other Baltic-Finnic traditions than in Estonian regilaul - those have often mythological connections representing mythological, ever-present or recurrent time-perception as 
well. There are, though, a few ballad-like plots, some of which have detected to have close parallels among the Scandinavian medieval ballads (Ots 1996). Arne Merilai, analyzing the time models of Estonian traditional and literary ballads, hypothesises that Estonians have adopted the historical or linear time model via foreign, European patterns, the original one being parallelistic or recurrent time model. He proposes that ballads present the common Western European concept of time, and considers the appearance of time as the metaphysical base of the narration (Merilai 1997). Mall Hiiemäe, who has thoroughly studied the Estonian folk calendar, has noted - similarly to the regilaul-tradition - the prominence of collective values in Estonian calendar customs to be in connection of the cyclical time-perception, and states the historical time conception to be an aspect of individualistic world-view, inter alia evident in the Christian canonical texts and world view (Hiiemäe 2009). Historical deeds and events are relevant neither in the framework of the functionality of older Estonian folk-songs, nor in the settlement history of Estonians, having been living in the area of present Estonia thousands of years without undertaking any massive migrations or significant conquers in historical times.

The origins of the secular vernacular rhymed song tradition have been acknowledged to lie in the medieval courtly milieu of France, and/or medieval cities from where it spread on all over Europe (see e.g. Colbert 1989; Vargyas 1983; Ward 1978). In the class-society of the medieval times the collective thinking faded off in the courts as well as in the cities and towns and individualism gained weight. Valter Lang, relying on archaeological evidences from late Bronze Age until the $13^{\text {th }}$ century, states that the settlements in Estonia reveal low and rather hidden stratification of the society until year 500 . The differences between the social classes start to grow afterwards but still remain modest in Estonia compared, for example, to the Lithuanian society (Lang 2008). In the subsequent period from the $13^{\text {th }}$ century onwards Saxon and German colonists formed the higher class of society, i.e. the feudal owners of the land and local people, the clericals, and part of the craftsmen. The foreign upper class of invaders is probably one the reasons why stratification among Estonians remained quite moderate for hundreds of years, and Estonians retained their collective thinking, along with the poetic culture peculiar to it for that long.

The singing of regilauls was deprecated by church, apparently mostly because the singing formed often part of the non-Christian rituals. The extent of deprecation was depending on the time, location and the confession in question. As there are quite a lot of songs mocking, derogating and even vituperating "Saxons", i.e. landowners, the song tradition probably served as a kind of protest against the serfdom, and could not be really approved by the foreign upper class. The style of regilaul-singing has been sometimes called by foreigners derogatively as screaming or non-singing (see e.g. an example in Laugaste 1963: 35-36). In the course of the $19^{\text {th }}$ century some Estonian intellectuals, with German-style education, publicly began to disapprove the singing of old songs, praising the ideals of European culture. Where the church or religious movements had spared the regilaul-tradition, the constant Europeanization, the cultural self-colonization, and changes in the socio-cultural 
background, all together contributed to the gradual fading of the tradition (cf. the discussion on the Europeanization processes in Hungarian poetics in Abondolo 2001: 275-278). Instead of the old tradition, the European-style rhymed songs were accepted and acquired. Rhymed songs were perceived as a part of European culture, i.e. with higher status, and suited better to the new, more individualistic society qua their content and functions.

The change from the stichic to the stanzaic form in the Estonian song-tradition did not thus comprise barely the change of the poetic form. A whole poetic system along with its form, thematic, functions, clichés, and time model, was replaced by another one, in the context of the cultural contacts and in reaction to the changes in the society and culture as well as in the value judgements and even in the structure of language (cf. Colbert 1989). All this happened in the complex process of Europeanization of Estonian people which included the rise of individuality, literacy, Christianity, and nationality.

\section{REFERENCES AND SOURCES}

Abondolo, Daniel

2001 A Poetics Handbook. Verbal Art in the European Tradition. Richmond, Surrey: Curzon Press.

Colbert, David

1989 The Birth of the Ballad. The Scandinavian Medieval Genre. Stockholm: Svenskt visarkiv (Skrifter utgivna av Svenskt visarkiv; 10).

Gasparov, M. L.

1996 A History of European Versification. Oxford: Clarendon Press

Hiebert Beissinger, Margaret

1988 Text and Music in Romanian Oral Epic. Oral Tradition 3 (3): 294-314 (http://journal.oraltradition. org/issues/3iii/beissinger).

Hiiemäe, Mall

2006 Kosmogoonilise harja otsimine. In : Lintrop, Addo (ed.), Regilaul-esitusja tôlgendus. Tartu: Eesti Kirjandusmuuseum (Eesti Rahvaluule Arhiivi toimetused; 23), 21-48.

2009 Miks ma ei taha rääkida kriisi ületamisest? Kriis?!? Eesti folkloristide 4._talvekonverents. Teesid. Tartu: EKM Teaduskirjastus, 5 (http://www.folklore.ee/rl/fo/konve/2009/ftk/teesid.pdf).

Laugaste, Eduard

1963 Eesti rahvaluuleteaduse ajalugu I. Tallinn: Eesti Riiklik Kirjastus.

Lintrop, Aado

2001 The Great Oak and Brother-Sister. Folklore [Tartu] 16: 34-56 (http://www.folklore.ee/folklore/ vol16/oak2.pdf).

Lang, Valter

2008 Eestlased ja leedulased - aegade algusest erinevad. Eesti Päevaleht 31.12.2008 (http://www.epl.ee/ $\operatorname{artikkel/453558).~}$ 
Lippus, Urve

2005 Linear Musical Thinking: A theory of musical thinking and the runic song tradition of Baltic Finnish peoples. Helsinki: University of Helsinki (Studia Musicologica Universitatis Helsingiensis; VII).

Lotman, Mihhail

1998 Värsisüsteemidest. Peamiselt eesti ja vene värsi näitel. Akadeemia 9-10: 1846-1874; 2058-2078.

Merilai, Arne

1997 Time models in Estonian traditional and literary Ballads. Folklore [Tartu] 3: 131-146 (http://www. folklore.ee/folklore/vol3/merilail.htm).

Ong, Walter J.

1982 Orality and Literacy: The Technologizing of the Word. London, New York: Routledge.

Ots, Loone

1996 Mehetapja naine skandinaavia keskaegses ballaadis. Rein Sepa 75. sünniaaastapäevale pühendatud konverentsi ettekandematerjalid (http://my.tele2.ee/rein_sepp/ots.htm).

Preminger, Alex and T. V. F. Brogan (eds.)

1993 The New Princeton Encyclopedia of Poetry and Poetics. Princeton, New Jersey: Princeton University Press.

Sarv, Mari

2008 Loomiseks loodud: regivärsimôōt traditsiooniprotsessis. Tartu: Eesti Kirjandusmuuseum (Eesti Rahvaluule Arhiivi Toimetused; 26).

Tampere, Herbert et al.

2003 Anthology of Estonian Traditional Music. Textbook. Recordings from the Estonian Folklore Archives 3. Tartu: Eesti Kirjandusmuuseum.

Tedre, Ülo

2008 Rahvaluule. In: Viires, A. and E. Vunder (eds.), Eesti rahvakultuur. Tallinn: Eesti Entsüklopeediakirjastus, 423-448.

Vargyas, Lajos

1983 Hungarian Ballad and the European Ballad Tradition. Budapest: Akadémiai Kiadó.

Viitso, Tiit-Rein

2003 Rise and development of the Estonian language. Estonian Language. Linguistica Uralica supplementary series. Volume 1 (ed. by Mati Erelt). Tallinn: Estonian Academy Publishers, 130-230.

Ward, Donald

1978 The Origin of the Ballad: Urban Setting or Rural Setting. In: Conroy, Patricia (ed.), Ballads and Ballad Research. Seattle: University of Washington, 46-57.

Wiik, Kalevi

1996 On the Baltic Sea Prosodic Area. In: Lehiste, Ilse and Jaan Ross (eds.), Estonian Prosody. Papers form a Symposium. Tallinn: Institute of Estonian Language. 


\section{VERZNE IN KITIČNE PESEMSKE OBLIKE V ESTONSKEM IZROČILU IN V EVROPI}

V̌́lanku skuša avtorica poiskati odgovor na vprašanje, zakaj sta dve plasti estonskega pesemskega izročila - ena pripada skupnemu baltsko-finskemu izročilu, druga pa evropski ritmizirani pesemski tradiciji in baladam - v mnogočem tako različni. Razišč razvoj pesemske tradicije v evropskem kontekstu, na podlagi zamiranja nekitičnih oblik pesmi in naraščanja kitičnih verznih oblik. Obe poetski načeli oblikovanja besedil sta bili poznani po vsej Evropi, toda starejsi, stihični princip, je bil večinoma zamenjan z rimanimi stancami oziroma skitično obliko in je prevladal povsod po Evropi.

$Z$ analizo funkcij in družbeno-kulturnega ozadja obeh plasti estonske pesemske tradicije je avtorica ugotovila, da je bilv zapletenem procesu evropeizacije estonskega naroda ves verzni poetski sistem, skupaj z oblikami, funkcijami, klišeji in časovnimi modeli, zamenjan s kitičnim, in to zaradi različnih kulturnih vplivov in na podlagi sprememb $v$ družbi in kulturi kakor tudi sprememb vrednostnih sodb in navsezadnje strukture jezika.

Dr. Mari Sarv, Estonian Folklore Archives, Estonian Literary Museum, Vanemuise 42, Tartu 51003, Estonia; mari@sarv.ee 